\title{
Phytochemical components and physiological activities of purple wheat bran 'Arriheuk' extracts
}

\author{
Hee-Yeon Jin $^{1}$, Sung-Hee Jeon ${ }^{1}$, Kyeong-Hoon $\mathrm{Kim}^{2}$, Chon-Sik Kang ${ }^{2}$, \\ Han-Seok Choi ${ }^{3}$, Young Youn ${ }^{1 *}$ \\ ${ }^{1}$ Imsil Cheese \& Food Research Institute, Imsil 55918, Korea \\ ${ }^{2}$ National Institute of Crop Science, RDA, Wanju 55365, Korea \\ ${ }^{3}$ Korea National College of Agriculture and Fisheries, Jeonju 54874, Korea
}

\section{자색밀(아리흑) 추출물의 기능성 성분 및 생리활성}

\author{
진희연 ${ }^{1} \cdot$ 전성희 $^{1} \cdot$ 김경훈 $^{2} \cdot$ 강천식 $^{2} \cdot$ 최한석 $^{3} \cdot$ 윤영 $^{1 *}$ \\ ${ }^{1}$ (재)임실치즈앤식품연구소, ${ }^{2}$ 국립식량과학원 밀연구팀, ${ }^{3}$ 한국농수산대학 농수산가공과
}

\begin{abstract}
This study aimed to identify the phytochemical compounds in purple wheat bran 'Arriheuk' extract, with water, $\mathbf{5 0 \%}$ ethanol and $\mathbf{7 0} \%$ ethanol and determine its physiological activities. Six types of flavonoids were identified in 'Amiheuk' extract using a HPLC analysis. The highest total polyphenol content was observed in the 70\% ethanol extract, while the highest total flavonoid content was obtained both from the water and the $70 \%$ ethanol extracts of 'Arriheuk'. 2,2-diphenyl-1-picrylhydrazyl free radical scavenging activity was significantly high in the 48-h water extract and the 12-h 70\% ethanol extract, while the 2,2'-azino-bis(3-ethylbenzothiazoline-6-sulfonic acid) free radical scavenging activity was not significantly different between the two extracts. Cell viability, determined by the 3-(4,5-dimethylthiazol-2-yl)-2,5-diphenyltetrazolium bromide (MTT) assay, was high for cells treated with 70\% ethanol extract. The apoptosis protective effect, confirmed by Hoechst staining, showed that the morphological features were significantly reduced in cells treated with the $70 \%$ ethanol extract. Oil-Red-O staining was used to confirm the protective effect of 'Arriheuk' extracts on the intracellular lipid accumulation in cells, and the results showed the best inhibitory effect was observed at the $70 \%$ ethanol extract. However, the effect decreased in a concentration dependent manner. These results may improve the usage of 'Arriheuk' as a food material in the future.
\end{abstract}

Key words : Arriheuk, purple wheat bran, phenolic compound, flavonoid, antioxidant activity

\section{서 론}

최근 우리 농산물에 대한 소비자들의 관심과 소비 증가로 우리 밀 가공제품의 수요와 소비는 증가하고 있다(Kim 등, 2014). 밀은 우리나라에서 쌀, 옥수수와 더불어 3 대 작물 중 하나로 국민 1 인당 소비량이 $32.4 \mathrm{~kg}$ 으로 쌀 다음으로 많으
며, 주 용도는 주식으로 생산과 소비가 이루어지고 있다 (Ham 등, 2015). 하지만, 이러한 밀의 대부분은 수입에 의존 하고 있으며, 국내 밀 생산량은 수입량 대비 $1.7 \%$ 비율로 (MAFRA, 2018), 국내 자급률이 매우 낮은 작물이다(Kwak 등, 2017). 이렇다보니 대부분 수입 밀에 의존하는 국내 제분 산업의 경우, 최근 기후변동에 의한 국제 곡물 가격 변동에

\footnotetext{
*Corresponding author. E-mail : kuburi79@icf.re.kr, Phone : +82-63-644-2188, Fax : +82-63-644-2189

Received 18 February 2021; Revised 09 April 2021; Accepted 13 April 2021.

Copyright (c) The Korean Society of Food Preservation.

This is an Open Access article distributed under the terms of the Creative Commons Attribution Non-Commercial License (http://creativecommons.org/licenses/by-nc/4.0) which permits unrestricted non-commercial use, distribution, and reproduction in any medium, provided the original work is properly cited.
} 
직접적인 영향을 받고 있어, 이러한 문제해결을 위해, 정부에 서는 국내 밭작물 자급률 향상을 위해 우리 밀의 재배 면적을 증가시키고는 있으나, 농가당 생산규모가 작고, 농지가 분산 되어 있으며, 벼 중심의 밀재배에 따른 조기수확 등으로 같은 품종 내에서도 균질도가 떨어져 수입 밀에 비해 품질이 낮게 평가되어, 제품 가공업체에서 가격 등의 이유로 기피하고 있 는 실정이다. 따라서 밀의 안정적인 수매처 확보가 어려워 생 산량 확대가 쉽지 않은 상황이다(Kim 등, 2018). 이에 농촌진 흥청 국립식량과학원에서는 국산 밀의 생산 및 소비 확대를 위하여 육종 프로그램을 통한 재래종 흑밀과 신미찰 품종을 인공 교배하여 자색의 밀 품종 ‘아리흑'을 개발하였다(Kim 등, 2018). '아리흑'은 자색을 띄는 품종으로 이러한 자색밀은 안 토시아닌, 폴리페놀 화합물 등을 다량 함유하고 있는 것으로 알려져 있으며(Hosseinian 등, 2008; $\mathrm{Hu}$ 등, 2007), 이러한 성 분들에서의 다양한 기능성을 기대할 수 있을 것이다. 또한, '아리흑'은 국내 밀 산업의 성장, 일반 농가의 무단 재배 및 판매 방지, 다른 품종과의 혼입을 방지하여, 농가의 안정적 판 로 확보를 통한 소득 보전을 위해 산업재산권(식물특허)에 등 록되어져 있다. 본 연구에서는 국내산 자색밀 '아리흑'에서의 유효성분 확인 및 다양한 기능성 효능 규명을 통한 기초자료 제공을 목적으로 하며, 이를 통한 우리 밀 생산 및 소비 확대 를 통한 국내 밀 산업 성장에 도움이 되고자 한다.

\section{재료 및 방법}

\section{자색밀 ‘아리흑' 추출물 제조}

본 연구에 사용된 아리흑은 자색을 띄는 자색밀로 2019년 에 수확된 것으로 국립식량과학원으로부터 제공받았다. 추출 용매로는 향후 일반식품 적용을 고려하여 물과 에탄올을 사 용하였다. 추출에 사용된 아리흑은 겨층을 제거한 통밀에 20
배의 물과 $50 \%$ 및 $70 \%$ 에탄올을 첨가하여 12 시간 간격으로 48 시간 동안 실온 $\left(18 \pm 2^{\circ} \mathrm{C}\right)$ 에서 추출하였고, 이러한 작업은 2 회 반복하였다. 추출된 용매는 여과하여 감압농축 $\left(60^{\circ} \mathrm{C}, 100\right.$ hpa) 후, 동결건조하였다. 분말 수율은 동결 건조된 분말 중 량을 추출에 사용한 원료의 중량으로 나누어 백분율(\%)로 나 타내었고, 이때 수율은 $2.2 \%$ 로 $70 \%$ 에탄올 추출물이 가장 높게 나타났다.

\section{HPLC 분석 조건}

아리흑의 페놀화합물 및 플라보노이드는 HPLC(Waters 2690, Waters, Milford, MA, USA)를 이용하였고, 검출기는 $\mathrm{PDA}($ Waters 996, Waters)를 사용하여 분석하였다. 아리흑 추출물 $0.02 \mathrm{~g}$ 을 취해 $70 \%$ methanol $1 \mathrm{~mL}$ 에 녹인 후 13,000 $\mathrm{rpm}$ 에서 10 분간 원심 분리하였다. Column은 Zorbax Eplipse XDB $\mathrm{C}_{18}(5 \mu \mathrm{m}, 4.6 \times 250 \mathrm{~mm}$, Agilent, Santa Clara, CA, USA)과 $C_{18}$ guard column $(5 \mu \mathrm{m}, 4.6 \times 20 \mathrm{~mm}$, Agilent, Santa Clara, CA, USA)을 사용하였다. 분석은 gradient mode로 진 행하였고, 이동상은 $0.1 \%$ formic acid를 함유하는 $10 \%$ acetonitrile 용액(A)과 $0.1 \%$ formic acid를 함유하는 $90 \%$ acetonitrile 용액(B)을 사용하였다. HPLC condition은 Table 1 과 같다.

\section{총폴리페놀 분석}

총폴리페놀은 Folin-Ciocalteu's 발색법(Oh 등, 2000)에 준 해 분석하였다. 시료 $1 \mathrm{~mL}$ 에 증류수 $7.5 \mathrm{~mL}$ 를 가한 후 3 분 간 방치시킨 다음 Folin-Ciocalteu $0.5 \mathrm{~mL}$ 를 첨가하고, $3.5 \%$ sodium carbonate anhydrous $1 \mathrm{~mL}$ 를 첨가해 1 시간 동안 방 치 후 $760 \mathrm{~nm}$ 에서 흡광도를 측정하였다. 표준물질은 gallic $\mathrm{acid}$ 를 사용하여 표준검량 곡선을 작성 후 총폴리페놀 함량

Table 1. HPLC conditions for analysis of phenolic compounds

\begin{tabular}{|c|c|c|c|c|c|c|}
\hline \multicolumn{2}{|c|}{ Instrument } & \multicolumn{5}{|c|}{ Waters 2690 (Water, Milford, MA, USA) } \\
\hline \multicolumn{2}{|c|}{ Column } & \multicolumn{5}{|c|}{$\begin{array}{l}\text { Zorbax Eplipse XDB } \mathrm{C}_{18}(5 \mu \mathrm{m}, 4.6 \times 250 \mathrm{~mm} \text {, Agilent, Santa Clara, CA, USA) } \\
\mathrm{C}_{18} \text { guard column }(5 \mu \mathrm{m}, 4.6 \times 20 \mathrm{~mm} \text {, Agilent, Santa Clara, CA, USA })\end{array}$} \\
\hline \multicolumn{2}{|c|}{ Mobile phase } & \multicolumn{5}{|c|}{$\begin{array}{l}\text { A: } 0.1 \% \text { formic acid, } 10 \% \text { acetonitrile } \\
\text { B: } 0.1 \% \text { formic acid, } 90 \% \text { acetonitrile }\end{array}$} \\
\hline \multicolumn{2}{|c|}{ Flow phase } & \multicolumn{5}{|c|}{$0.8 \mathrm{~mL} / \mathrm{min}$} \\
\hline \multicolumn{2}{|c|}{ Injection volume } & $10 \mu \mathrm{L}$ & & & & \\
\hline \multicolumn{2}{|c|}{ Detector } & $280 \mathrm{~nm}$ & & & & \\
\hline \multirow{3}{*}{ Gradient } & Time (min) & 5 & 10 & 40 & 45 & 50 \\
\hline & $\mathrm{A} \%$ & 100 & 85 & 30 & 100 & 100 \\
\hline & $\mathrm{B} \%$ & 0 & 15 & 70 & 0 & 0 \\
\hline
\end{tabular}


을 정량하였다.

\section{총플라보노이드 분석}

총플라보노이드는 시료 $1 \mathrm{~mL}$ 와 diethylene glycol $10 \mathrm{~mL}$ 를 혼합하고 $1 \mathrm{~N} \mathrm{NaOH}$ 용액 $1 \mathrm{~mL}$ 를 가하여 1 시간 반응시킨 후 $420 \mathrm{~nm}$ 에서 흡광도를 측정하였다(Dewanto 등, 2002). 분 석은 각 시료당 3 반복 실시하였고, 이 때 표준물질은 quercetin 을 사용하여 표준검량 곡선을 작성한 다음 총플라보노이드 함량을 구하였다.

\section{$\mathrm{DPPH}$ 자유 라디칼 소거활성 측정}

1,1-Diphenyl-2-picryhydrazyl(DPPH) 자유 라디칼 소거활 성은 Blois의 방법(Lee 등, 2001)을 변형하여 측정하였다. $0.1 \mathrm{mM} \mathrm{DPPH}$ 용액 $150 \mu \mathrm{L}$ 와 시료 $50 \mu \mathrm{L}$ 를 혼합하여 30 분 간 암소에서 반응시킨 후 $530 \mathrm{~nm}$ 에서 흡광도를 측정하였다.

\section{ABTS 자유 라디칼 소거활성 측정}

2-2'-Azino-bis3-ethylbenzothiazoline-6-sulphonic acid(ABTS) 자유 라디칼 소거활성은 potassium persulfate의 반응에 의해 생성된 $\mathrm{ABTS}$ 라디칼이 항산화 물질에 의해 제거되어 청록 색으로 탈색되는 것을 이용한 방법(Blois, 1977)이다. $2.4 \mathrm{mM}$ potassium persulfate 용액을 $7 \mathrm{mM} \mathrm{ABTS}$ 가 되도록 용해시 킨 다음 암소에서 24시간 동안 반응시켰다. ABTS solution을 형성시킨 후 $630 \mathrm{~nm}$ 에서 흡광도 값이 $0.70 \pm 0.02$ 가 되게 증 류수로 희석하였다. 희석된 용액과 각 시료를 $1: 1$ 로 혼합한 후 $630 \mathrm{~nm}$ 에서 흡광도를 측정하였다.

\section{세포배양}

본 실험에 사용된 간암세포주 AML-12는 American type culture collection(ATCC)에서 구입하였으며, $10 \% \mathrm{FBS}$ (Gibco, Grand island, NY, USA)와 penicillin(100 units $/ \mathrm{mL})$ 이 함유된 $\operatorname{DMEM}(\mathrm{Gibco})$ 배지를 사용하여 $37^{\circ} \mathrm{C}, 5 \% \mathrm{CO}_{2}$ 배양기에서 배양하였다. 지방증(steatosis)을 일으키기 위해 palmitate를 isopropanol에 녹인 다음, $1 \%$ 의 bovine serum albumin(BSA) 을 함유한 DMEM 배지에 conjugation시켜 사용하였다.

\section{세포생존율 측정}

세포생존율을 확인하기 위해 MTT assay로 측정하였다. AML-12 세포는 $1 \times 10^{5}$ cells/well로 분주하여 24시간 동안 배양한 후, 배지를 제거하고 $0.5 \mathrm{mM}$ palmitate로 유도시킨 후 추출물 시료를 농도별로 처리하였다. 24시간 배양한 후 MTT(Sigma-Aldrich Co., St. Louis, MO, USA) 시약을 10 $\mu \mathrm{L}$ 처리하여 4시간 배양한 후 배지와 MTT 시약을 제거하고 활성이 있는 세포들이 MTT를 환원하여 생성한 formazan crystal을 측정하기 위해 $\mathrm{DMSO}$ 를 $100 \mu \mathrm{L}$ 를 넣고 $570 \mathrm{~nm}$ 에 서 흡광도를 이용하여 세포 생존율을 측정하였다.

\section{형광염색}

세포 배양이 끝난 뒤 세포를 PBS로 희석한 다음 1,000 $\mathrm{rpm}$ 에서 10 분간 원심분리하여 세척하고, 동일한 방법으로 한 번 더 세척한 후 Hoechst 33258 핵 염료를 도포하고, $37^{\circ} \mathrm{C}$ 암실에서 10 분 동안 염색하였다. 염색한 세포를 PBS로 3 회 세척한 후 형광현미경(EVOS M5000, Leica Co., Bothell, Washington, Germany)으로 이미지를 촬영하였다.

\section{Oil-Red-O(ORO) 염색}

Oil-Red-O staining은 배양한 세포를 $3 \times 10^{5}$ cells/well에 분 주하여 24시간 동안 부착시킨 후 추출물 시료를 농도별로 처 리하고, 24시간 동안 배양하였다. 24시간이 지난 후 PBS로 3 회 세척하고, $10 \%$ formalin 용액을 첨가하여 10 분간 고정하 였다. 그 후 formalin을 제거하고 PBS로 세척한 후, 미리 제 조해 둔 ORO solution으로 세포 내 축적된 지방성분들을 충 분히 염색한 후, $\mathrm{PBS}$ 를 이용하여 세척하고 건조시켰다. 세포 내 축적된 지방성분과 결합한 $\mathrm{ORO}$ 는 isopropyl alcohol을 이 용하여 모두 용출시킨 후, spectrophotometer를 이용하여 490 $\mathrm{nm}$ 에서 흡광도를 측정하였다.

\section{세포 내 중성지방 함량 측정}

AML-12 세포를 $3 \times 10^{5}$ cells/well로 분주하여 24시간 배양 한 후 추출물 시료를 농도별로 처리하고 24시간 동안 배양하였 다. 24시간 후 배양액을 균질화 한 다음 chloroform, methanol 및 증류수(2/1/1) 혼합액을 가하여 지방성분을 추출하였으며, 지방추출물은 isopropanol에 희석하여 보관하면서 사용하였 다. 중성지방은 측정 키트(Asan Pharmaceutical)를 이용하여 측정하였다.

\section{통계처리}

모든 데이터는 3 회 반복 측정하였으며, 평균(mean)표준 편차(standard deviation, SD)로 표현하였고, 결과에 대한 통 계분석은 SPSS Statistics(ver. 12.0K, SPSS Inc., Chicago, $\mathrm{IL}, \mathrm{USA})$ 프로그램을 사용하여 $\mathrm{p}<0.05$ 수준에서 시료들 간 의 차이를 Duncan's multiple range test에 의해 유의성을 검 증하였다.

\section{결과 및 고찰}

\section{페놀화합물 및 플라보노이드 동정}

페놀류 화합물인 플라보노이드는 대부분 식물에 유리상태 
로 존재하며, 물에 녹지 않고 유기용매에 잘 녹는다. 또한 항 균, 항암, 항바이러스, 항알레르기, 항산화 및 함염증 활성을 지니고, 독성은 거의 나타나지 않는 것으로 보고되고 있다 (Lee 등, 1999). 또한, 자색 밀 페놀화합물 연구결과를 바탕으 로 4종의 화합물(protocatechuic acid, caffeic acid, p-coumaric acid, ferulic acid)을 분석하여 용출시간 및 함량을 확인하였 다(Gamil 등, 2019). 이와 같이 아리흑 추출물의 유효 성분 분석을 위해 HPLC 분석한 결과(Fig. 1), 개별화합물 용출시 간대 6종 이상의 peak를 확인하였고, anthocyanin 색소를 구 성하고 있는 것으로 알려진 acyl compounds 등을 대상으로
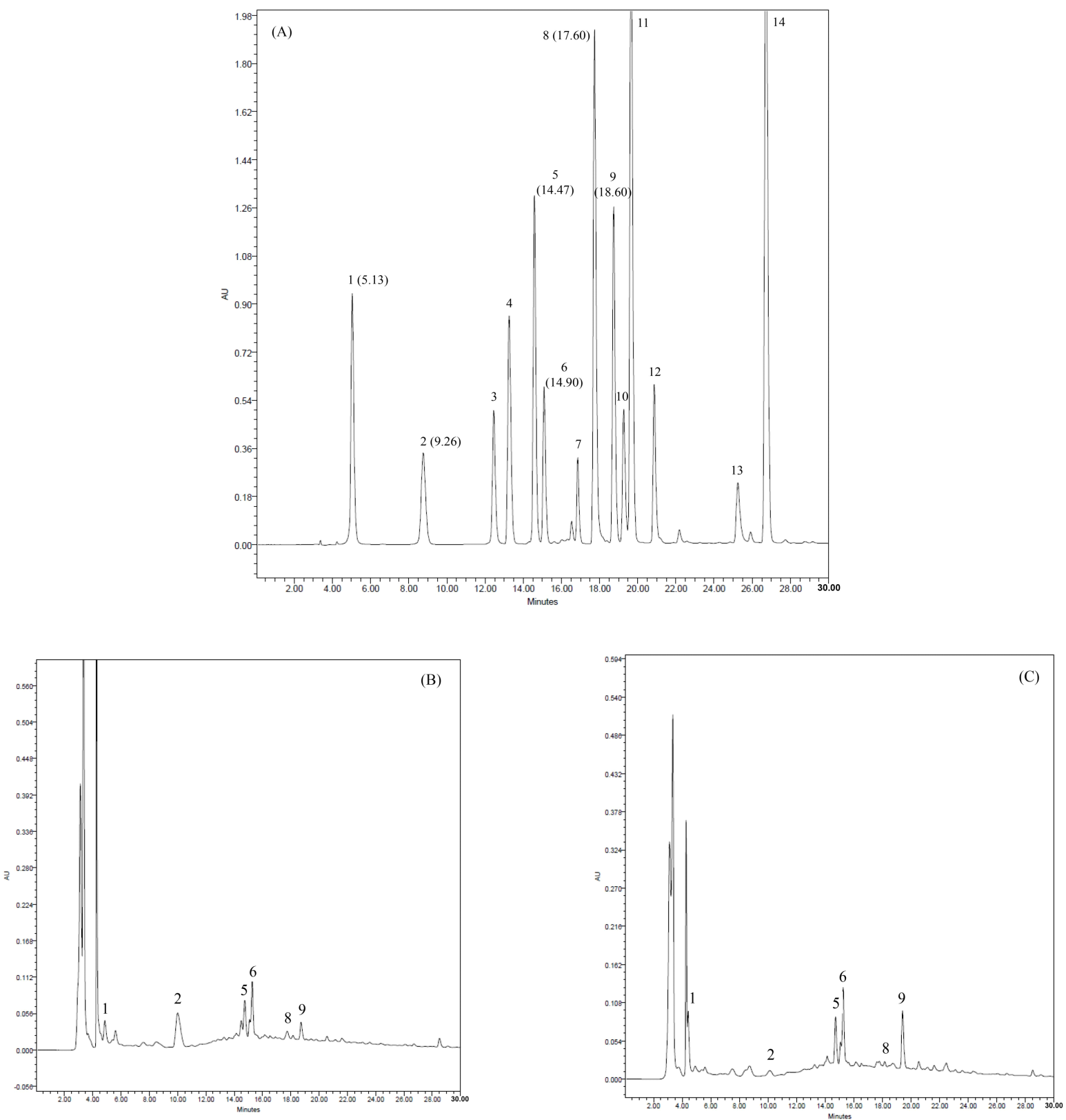

Fig. 1. HPLC chromatograms of phenolic compounds and flavonoid contents of 'Arriheuk' extracts according to extraction solvents and extraction times 1-14 (1, gallic acid; 2, protocatechuic acid; 3, chrologenic; 4, 4-hydroxybenzoic; 5, caffeic acid; 6, isovanillic acid; 7, rutin; 8, p-coumaric; 9, ferulic acid; 10, taxifolin; 11, trans-coumaric; 12, rosmarinic; 13, quercetin; 14, trans-cinnamic).

A, standard; B, water extract for $12 \mathrm{~h}$; C, water extract for $24 \mathrm{~h}$; D, water extract for $36 \mathrm{~h}$; E, water extract for $48 \mathrm{~h}$; F, $50 \%$ EtOH extract for $12 \mathrm{~h}$; G, $50 \% \mathrm{EtOH}$ extract for $24 \mathrm{~h} ; \mathrm{H}, 50 \% \mathrm{EtOH}$ extract for $36 \mathrm{~h} ; \mathrm{I}, 50 \% \mathrm{EtOH}$ extract for $48 \mathrm{~h} ; \mathrm{J}, 70 \% \mathrm{EtOH}$ extract for $12 \mathrm{~h}$; K, $70 \%$ $\mathrm{EtOH}$ extract for $24 \mathrm{~h}$; L, 70\% EtOH extract for $36 \mathrm{~h}$; M, 70\% EtOH extract for $48 \mathrm{~h}$. 

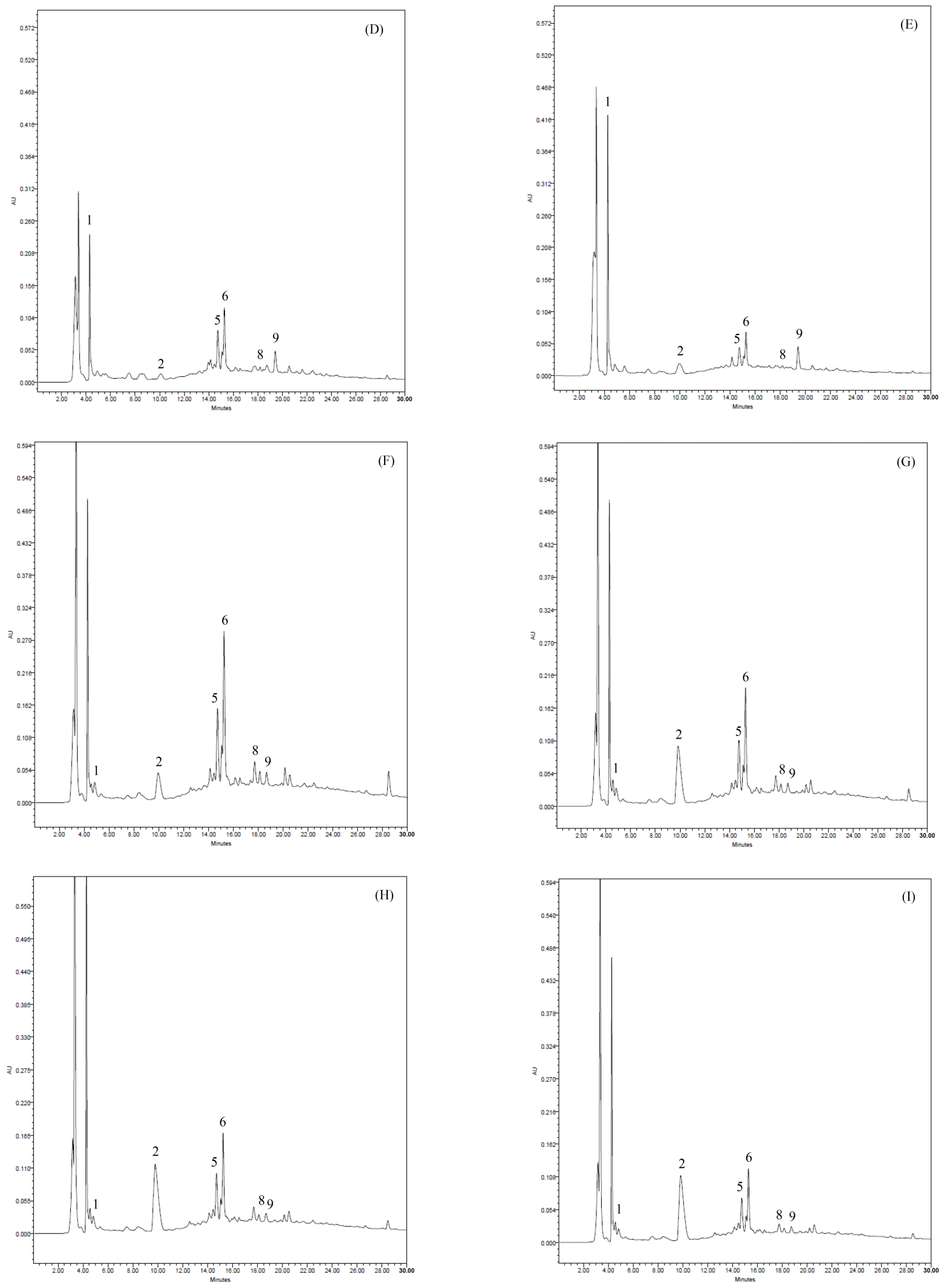

(Continued) 

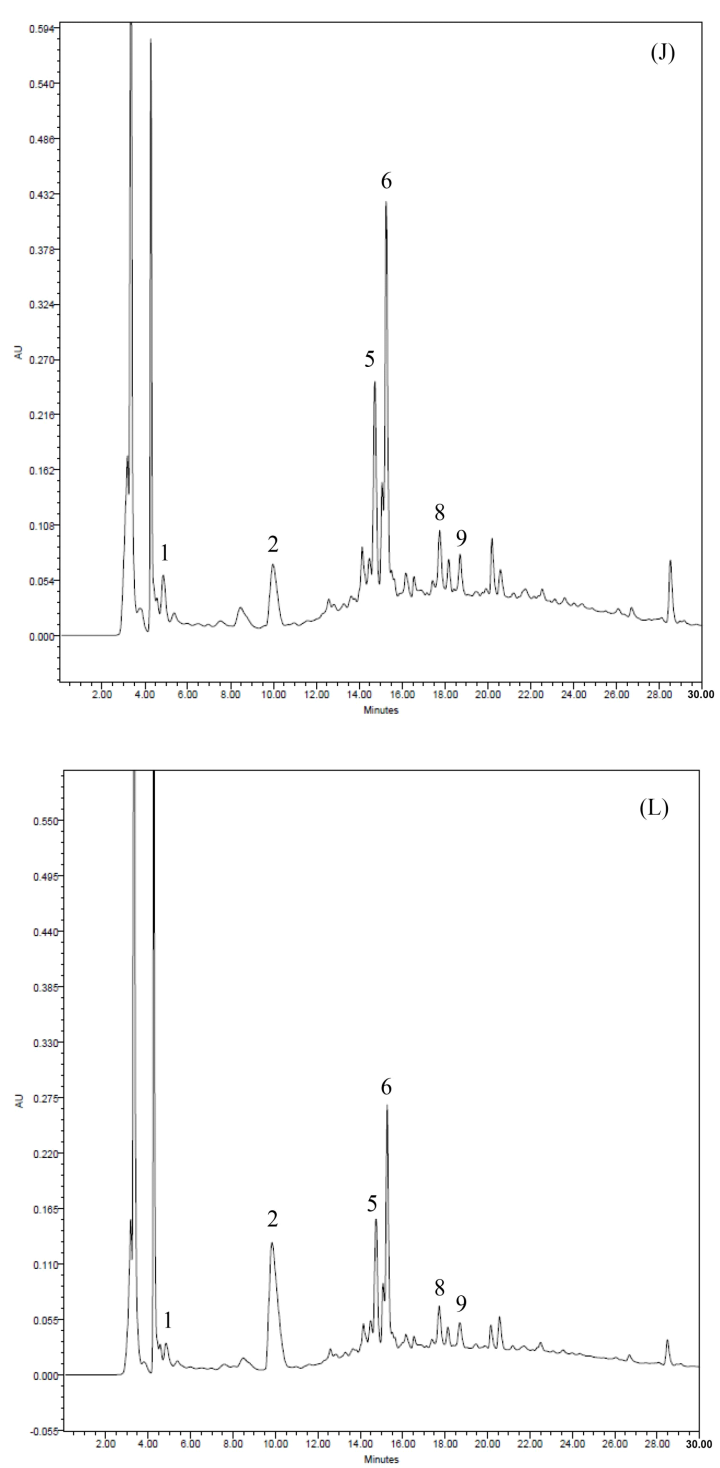

HPLC 분석을 통해 동일 용출시간대의 peak를 관찰하였다. 그 결과, gallic acid(5.13분), protocatechuic acid(9.26분), caffeic acid(14.47분), isovanillic acid(14.90분), p-coumaric (17.60분) 및 ferulic acid(18.60분)로 구성되어 있음을 확인하 였고, 확인된 성분들의 정량값은 다음과 같았다(Table 2). 즉, $70 \%$ 에탄올 추출물에서 gallic acid $648.6 \mu \mathrm{g} / \mathrm{g}$, protocatechin $1,343.2 \mu \mathrm{g} / \mathrm{g}$, caffic acid 2,170.6 $\mu \mathrm{g} / \mathrm{g}$, isovanillic acid $1,567.4 \mu \mathrm{g} / \mathrm{g}, \mathrm{p}$-coumaric $377.4 \mu \mathrm{g} / \mathrm{g}$, 및 ferulic acid 478.9 $\mu \mathrm{g} / \mathrm{g}$ 의 함량을 나타낸 12 시간 처리군에서 가장 높은 함량을 나타내었고, 물 추출물 중에서 gallic acid $479.7 \mu \mathrm{g} / \mathrm{g}$, protocatechin $528.7 \mu \mathrm{g} / \mathrm{g}$, caffic acid $890.9 \mu \mathrm{g} / \mathrm{g}$, isovanillic acid $526.6 \mu \mathrm{g} / \mathrm{g}$, p-coumaric $112.8 \mu \mathrm{g} / \mathrm{g}$ 및 ferulic acid 388.0
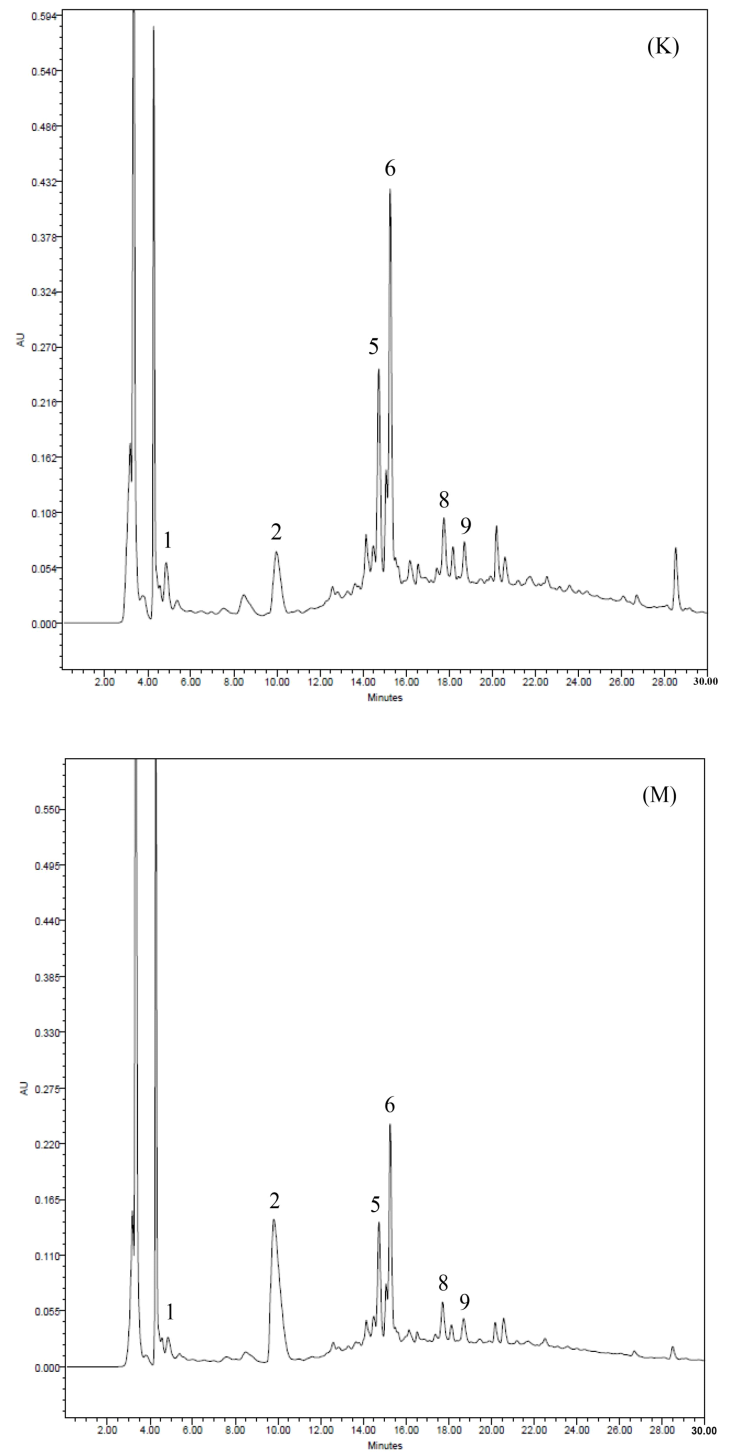

(Continued)

$\mu \mathrm{g} / \mathrm{g}$ 으로 48 시간 처리군에서 함량이 가장 높게 확인되었다. 이러한 결과는 자색 밀에서 다른 밀 품종과 달리 isovanillic acid와 ferulic acid의 함량이 높았다는 Liu 등(2010)의 결과 와 일치하였다. 플라보노이드는 주로 flavonols, flavones, cathechins 및 flavanones 등으로 구성되어 있으며, 구조에 따 라 특정 플라보노이드는 항산화 및 항균성 등 다양한 생리활 성을 가지고 있는 것으로 보고되고 있다(Middleton, 1994). 식품 항산화제인 protocatechuic acid는 요오드화메틸과 수산 화칼륨과 함께 가열하여 생기는 isovanillic acid를 비누화 시 키며, ferulic acid는 식물 세포벽의 풍부하게 들어 있는 성분 으로 활성산소를 중화하는 항산화 작용 및 혈당강하와 콜레 스테롤 저하 효과가 있는 것으로 알려져 있다(Kim 등, 2019). 
Table 2. Flavonoids components of 'Arriheuk' extracts according to extraction solvents and extraction times

\begin{tabular}{cccccccc}
\hline & Gallic acid & Protocatechuic acid & Caffeic acid & Isovanillic acid & p-Coumaric & Ferulic acid & Total \\
\hline W_12 & 161.5 & 364.0 & 401.5 & 276.9 & 30.6 & 128.5 & 1,363 \\
W_24 & 143.7 & 809.3 & 756.2 & 526.7 & 66.5 & 172.0 & 2,474 \\
W_36 & 158.9 & 422.2 & 756.0 & 521.3 & 63.6 & 185.6 & 388.0 \\
W_48 & 479.7 & 528.7 & 890.9 & 526.6 & 112.8 & 2,107 \\
E50_12 & 407.0 & 640.5 & $1,284.4$ & $1,161.7$ & 267.3 & 275.4 & 4,936 \\
E50_24 & 181.0 & 544.6 & $1,075.3$ & 654.7 & 185.9 & 283.1 \\
E50_36 & 155.8 & 514.2 & 907.1 & 409.3 & 161.8 & 230.9 \\
E50_48 & 14.5 & 317.2 & 791.9 & 499.1 & 117.7 & 225.0 \\
E70_12 & 648.6 & $1,343.2$ & $2,170.6$ & $1,567.4$ & 377.4 & 478.9 \\
E70_24 & 295.4 & 860.1 & $1,557.1$ & $1,182.6$ & 294.1 & 324 \\
E70_36 & 199.0 & 673.6 & $1,155.6$ & 928.0 & 267.1 & 6,586 \\
E70_48 & 200.5 & 627.9 & $1,228.6$ & 856.1 & 250.3 & 360.6 \\
\hline
\end{tabular}

${ }^{1)} \mathrm{W} \_12$, water extract for $12 \mathrm{~h}$ at R.T.; W_24, water extract for $24 \mathrm{~h}$ at R.T.; W_36, water extract for $36 \mathrm{~h}$ at R.T.; W_48, water extract for $48^{-} \mathrm{h}$ at R.T.

${ }^{2)} \mathrm{E} 5012,50 \% \mathrm{EtOH}$ extract for $12 \mathrm{~h}$ at R.T.; E50 24, 50\% EtOH extract for $24 \mathrm{~h}$ at R.T.; E50 36, 50\% EtOH extract for $36 \mathrm{~h}$ at R.T.; E50 48 , $50 \%$ EtOH extract for $48 \mathrm{~h}$ at R.T.

${ }^{3)} \mathrm{E} 70 \quad 12,70 \%$ EtOH extract for $12 \mathrm{~h}$ at R.T.; E70 24, 70\% EtOH extract for $24 \mathrm{~h}$ at R.T.; E70 36, 70\% EtOH extract for 36 h at R.T.; E70 48 , $70 \% \mathrm{EtOH}$ extract for $48 \mathrm{~h}$ at R.T.

\section{총폴리페놀 및 총플라보노이드 함량}

아리흑 추출물의 총폴리페놀 및 총플라보노이드 함량은 다 음과 같다(Fig. 2). 물 추출물은 12시간에 $17.12 \pm 0.28 \mathrm{mg} / \mathrm{g}$, 24시간에 $19.11 \pm 0.35 \mathrm{mg} / \mathrm{g}$ 및 48시간에 $19.81 \pm 0.64 \mathrm{mg} / \mathrm{g}$ 이 었고, $50 \%$ 에탄올 추출물은 12 시간에 $16.54 \pm 0.28 \mathrm{mg} / \mathrm{g}, 24$
시간에 $25.62 \pm 0.11 \mathrm{mg} / \mathrm{g}$ 및 48 시간에 $19.87 \pm 0.32 \mathrm{mg} / \mathrm{g}$ 을 나타 내었으며, $70 \%$ 에탄올 추출물은 12 시간에 $33.60 \pm 0.66 \mathrm{mg} / \mathrm{g}$, 24시간에 $28.19 \pm 0.41 \mathrm{mg} / \mathrm{g}$ 및 48시간에 $29.54 \pm 0.79 \mathrm{mg} / \mathrm{g}$ 으 로, 추출용매 중 에탄올 비율이 높을수록 총폴리페놀 함량도 높게 나타남을 확인하였다. 또한, 아리흑의 용매별 처리시간
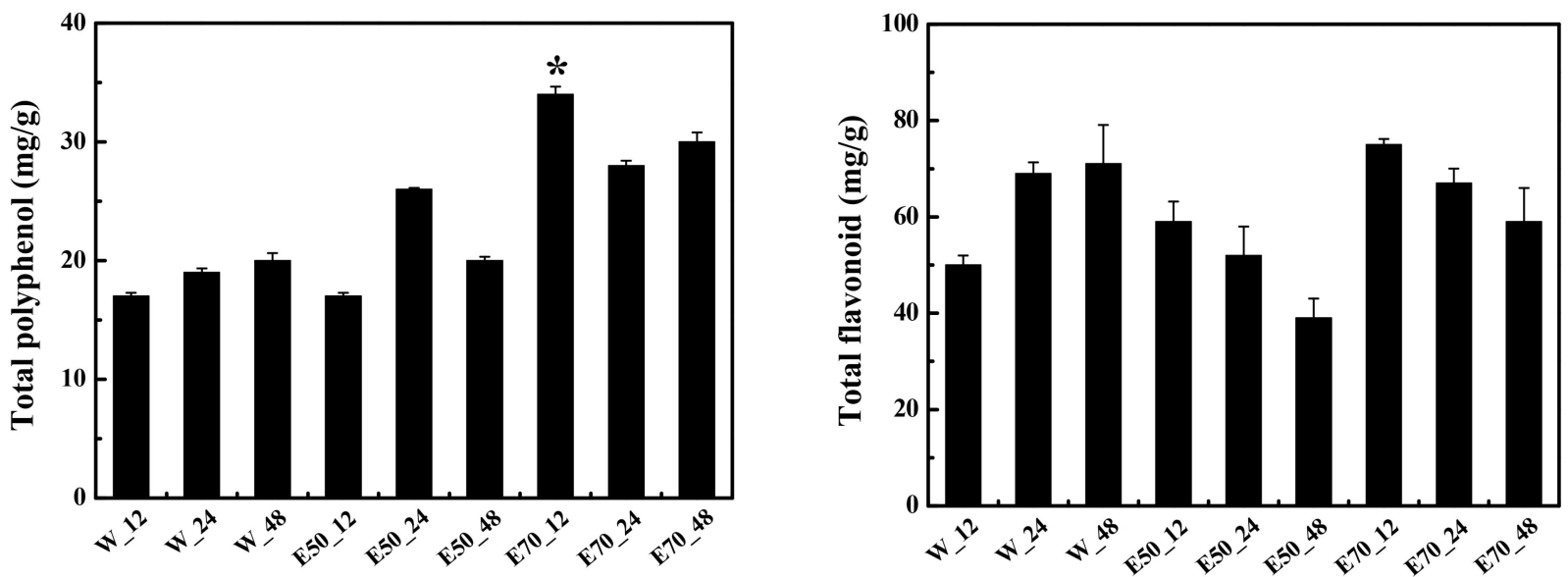

Fig. 2. Total polyphenolics and total flavonoid contents of 'Arriheuk' extracts according to extraction solvents and extraction times.

Total polyphenol: Values were mean \pm SD using gallic acid as a standard. All sample concentration: $1 \mathrm{mg} / \mathrm{mL}$. Symbols within a column indicate significant differences $(\mathrm{p}<0.05)$ from each other at $\alpha=0.05$ as determined by Duncan's multiple range test.

Total flavonoid: Values were mean $\pm \mathrm{SD}$ using quercetin as a standard. All sample concentration: $1 \mathrm{mg} / \mathrm{mL}$. All values were not significantly different $(\mathrm{p}<0.05)$. 
에 따른 총플라보노이드 함량은 물 추출물에서 추출시간이 길어짐에 따라 함량이 $50.00 \pm 2.00 \mathrm{mg} / \mathrm{g}$ (12시간), $68.67 \pm 2.31$ $\mathrm{mg} / \mathrm{g}$ (24시간) 및 $71.33 \pm 8.08 \mathrm{mg} / \mathrm{g}$ (48시간)으로 높게 나타났 으며, $50 \%$ 에탄올 추출물에서는 $59.33 \pm 4.19 \mathrm{mg} / \mathrm{g}$ (12시간), $52.00 \pm 6.00 \mathrm{mg} / \mathrm{g}$ (24시간), $38.67 \pm 4.05 \mathrm{mg} / \mathrm{g}$ (48시간) 및 $70 \%$ 에탄올 추출물에서는 $74.67 \pm 1.15 \mathrm{mg} / \mathrm{g}$ (12시간), $66.67 \pm 3.06$ $\mathrm{mg} / \mathrm{g}$ (24시간), $59.33 \pm 7.02 \mathrm{mg} / \mathrm{g}$ (48시간)으로 추출시간이 길 어짐에 따라 함량이 줄어들었다. 아리흑은 특수한 색과 고유 한 맛을 주는 페놀성 화합물이 존재하며, phenol류, phenolic acid류, phenylpropanoid류 및 flavonoid류 등이 대부분 항균, 항산화, 항암 등에 효과가 있는 것으로 보고되어 있고, 산화 를 억제하는 작용을 가진 물질로 알려져 있다(Kim 등, 1999). 아리흑 추출물의 폴리페놀과 플라보노이드 함량을 조사한 결 과, 이들 항산화 기능을 하는 물질들이 많아 상당한 항산화 활성이 있을 것으로 예상된다.

\section{$\mathrm{DPPH}$ 및 $\mathrm{ABTS}$ 자유 라디칼 소거활성능}

아리흑 추출물의 DPPH 자유 라디칼 소거활성 측정결과는 대조구 ascorbic $\operatorname{acid}(68 \%)$ 기준시 물 추출 48 시간에서 $170.80 \pm 4.61 \%$ 및 $70 \%$ 에탄올 추출 12 시간에서 $176.50 \pm 2.30 \%$ 로 가장 높은 항산화 활성을 나타내었고(Fig. 3), ABTS 자유 라디칼 소거활성 함량은 유의적인 차이 없이 $70 \%$ 에탄올 추 출물(12시간 $59.61 \pm 1.28 \%, 24$ 시간 $61.25 \pm 0.65 \%$ 및 48 시간 $61.08 \pm 3.95 \%)$ 에서 높게 나타났다. 이러한 이유는 폴리페놀 화합물의 종류에 따라 다른 라디칼 소거 활성을 보이고, 페놀 물질의 종류에 따라 두 기질에 결합하는 정도의 차이와 라디
칼을 제거하는 능력이 다른 것으로 보인다(Hyun 등, 2011; Wang 등, 1998). 항산화활성은 자유 라디칼에 전자를 공여하 고, 식품 중의 지방질 산화를 억제하는 특성을 가지고 있다. 또한 노화를 억제시키는 역할을 하며, 질병과 노화를 방지하 는데 대단히 중요한 역할을 한다(Kim 등, 2001).

\section{세포사멸 보호효과}

아리흑 추출물의 세포생존율을 측정하기 위해 $0.5 \mathrm{mM}$ palmitate를 처리한 세포에 시료를 처리한 후 MTT assay로 측 정하였다(Fig. 4). 먼저, $0.5 \mathrm{mM}$ palmitate 처리군은 무처리군 대비 $50 \%$ 이상의 세포 생존율을 확인하였고, AML-12 세포 내 palmitate로 인한 세포독성이 유도되었음을 확인할 수 있 었으며, 에탄올 함량이 높은 추출물에서 세포생존율이 증가 하는 경향을 보였다. 또한, $0.5 \mathrm{mM}$ palmitate를 처리하여 세 포독성을 유도한 AML- 12 세포에 $70 \%$ 에탄올 추출물을 처 리하여 세포생존율을 확인한 결과, $62.00 \pm 3.00 \%(50 \mu \mathrm{g} / \mathrm{mL})$, $67.67 \pm 4.51 \%(100 \mu \mathrm{g} / \mathrm{mL}), 71.33 \pm 3.51 \%(250 \mu \mathrm{g} / \mathrm{mL})$ 및 $73.67 \pm$ $5.13 \%(500 \mu \mathrm{g} / \mathrm{mL})$ 로 에탄올 함량이 높은 추출물에서 세포 생존율이 증가하는 경향을 보였다. 이러한 결과를 바탕으로 세포생존율이 가장 높게 확인된 $70 \%$ 에탄올 추출물에서 apoptosis 보호효과를 확인하고자 Hoechst staining을 실시하 였다. 즉, $0.5 \mathrm{mM}$ palmitate 처리군에서는 핵의 형태가 응축 되고, DNA 분절과 같은 형태학적 관찰을 확인할 수 있었던 반면, $70 \%$ 에탄올 추출물을 처리한 세포에서는 핵의 형태 응 축 및 DNA 분절과 같은 형태학적 특징이 현저히 감소됨을 확인할 수 있었다. 이상의 결과를 통해 본 연구에서는 아리흑
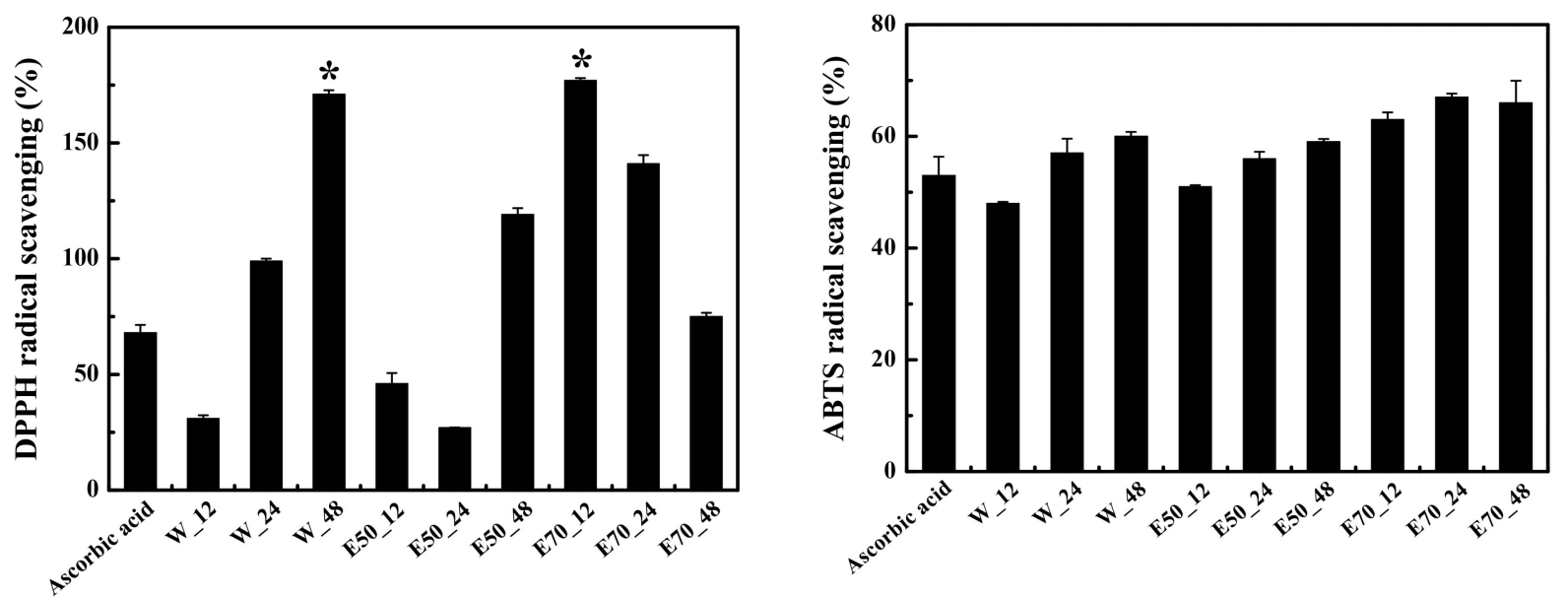

Fig. 3. DPPH radical scavenging activities and ABTS radical scavenging activities of 'Arriheuk' extracts according to extraction solvents and extraction times.

$\mathrm{DPPH}$, values were mean \pm SD. Symbols within a column indicate significant differences $(\mathrm{p}<0.05)$ from each other at $\alpha=0.05$ as determined by Duncan's multiple range test.

ABTS, values were mean \pm SD. All values were not significantly different $(p<0.05)$. 
(A)
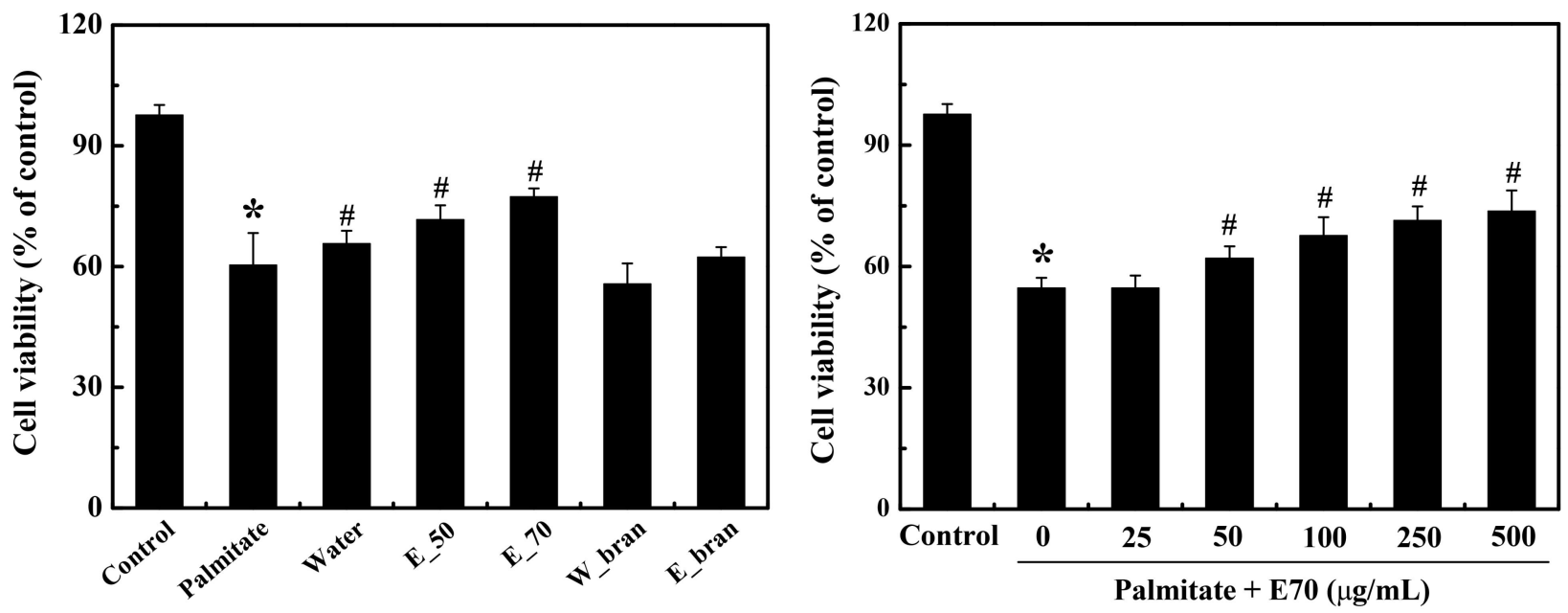

(B)

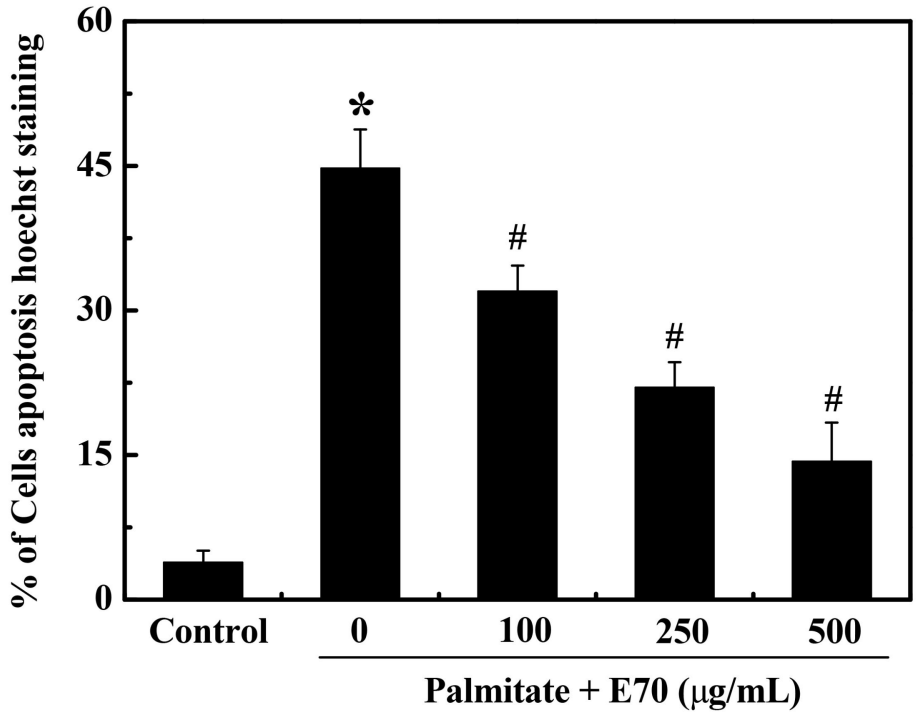

Fig. 4. 'Arriheuk' extracts protect against palmitate-induced cytotoxicity on AML-12 cell (A) cell viability measurement by MTT assay, (B) confirmation of apoptosis by Hoechst stain.

Values were mean \pm SD. Different symbols within a column indicate significant differences $\left({ }^{\sharp} \mathrm{p}<0.05\right)$ from each other at $*=0.05$ as determined by Duncan's multiple range test.

추출물이 palmitate로 인한 세포사멸에 대한 보호효과가 있음 을 확인하였다.

\section{세포 내 지방축적 억제효과}

아리흑 추출물의 palmitate로 야기된 세포 내 지방축적에 미치는 영향을 확인하고자 Oil-Red-O stain을 통해 확인하였 고, 결과는 다음과 같았다(Fig. 5). 먼저, AML-12 세포에 0.5 $\mathrm{mM}$ palmitate를 처리하여 세포 내 지방축적을 유도하고,
Oil-Red-O 염색법을 통한 세포내 지방축적 정도를 확인한 결 과, 세포 내 축적된 지방을 따라 빨강게 염색된 결과를 확인 할 수 있었다. 반면에, 아리흑 추출물 처리군에서는 세포 내 축적된 지방이 억제되었음을 확인할 수 있었고, 이는 추출물 의 에탄올 함량이 높을수록 억제 효과가 높은 것을 확인할 수 있었다. 또한, 세포 내 중성지방 함량을 정량하여 확인한 결과에서도 추출물의 에탄올 함량이 높을수록 세포 내 중성 지방 함량을 감소시킴을 확인할 수 있었다. 
(A)
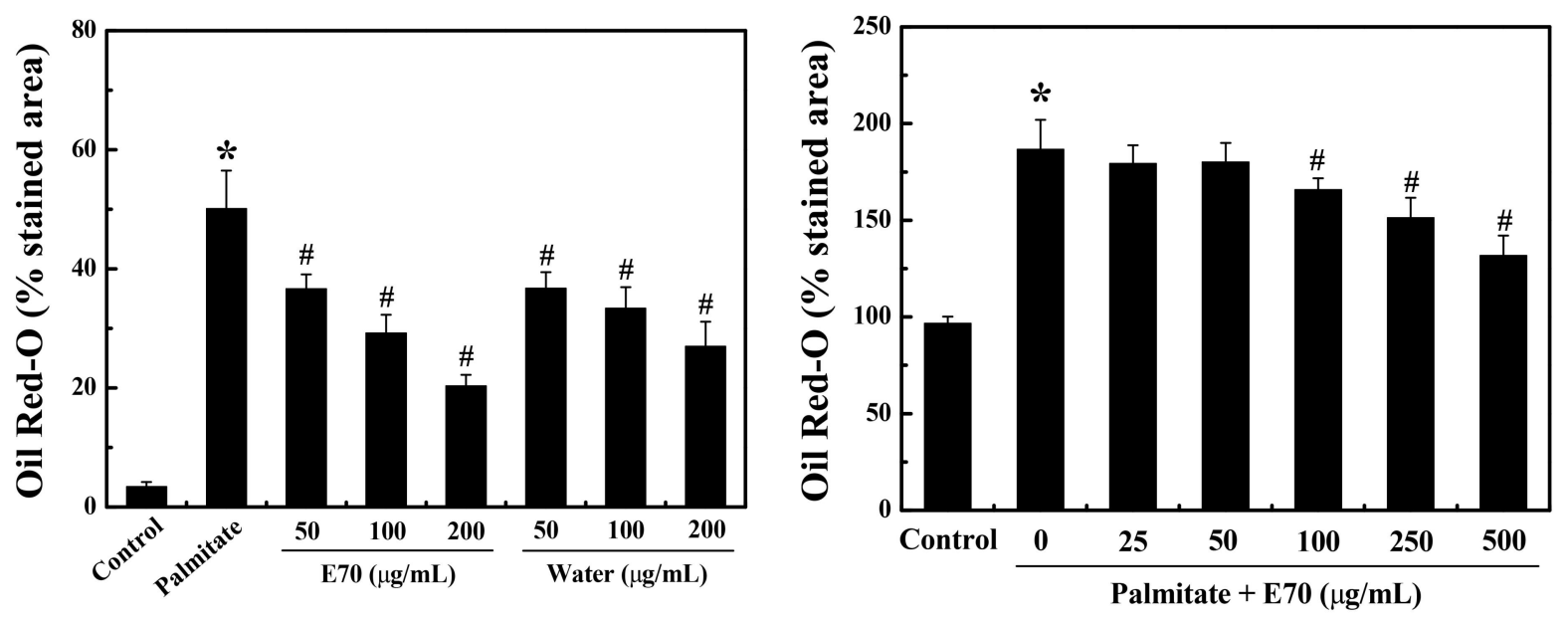

(B)
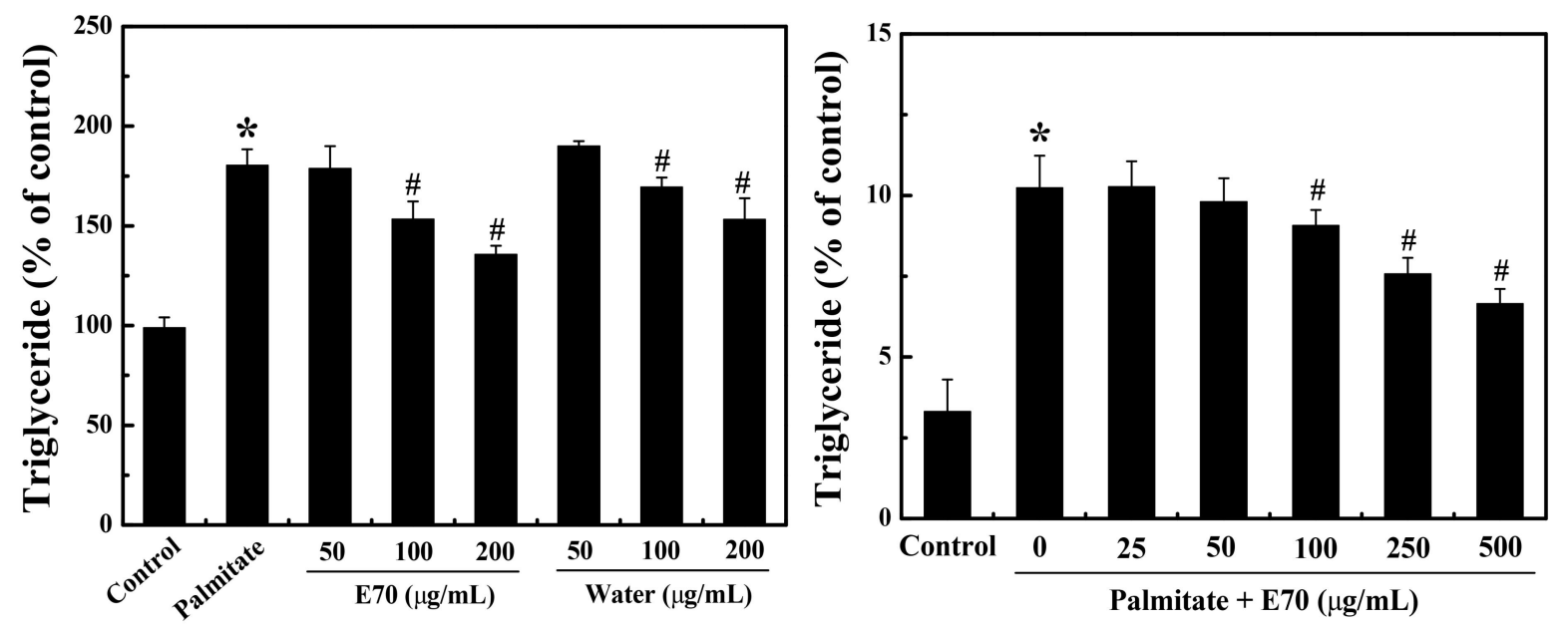

Fig. 5. 'Amiheuk' extracts regulates lipid accumulation caused by palmitate on AML-12 cells (A) Oil-Red-O stain for lipid content staining was measured in palmitate-treat cells (B) triglyceride level was measured in palmitate-treated cells.

Values were mean \pm SD. Different symbols within a column indicate significant differences $(* \mathrm{p}<0.05)$ from each other at $*=0.05$ as determined by Duncan's multiple range test.

이에 본 실험에서는 지방축적 억제효과가 가장 높았던 아 리흑 $70 \%$ 에탄올 추출물에서의 농도에 따른 효과를 확인하 고자 아리흑 $70 \%$ 에탄올 추출물을 100,250 및 $500 \mu \mathrm{g} / \mathrm{mL}$ 의 농도로 AML-12 세포에 처리한 다음, palmitate로 야기된 지 방축적에 대한 효능을 확인하였다. AML-12 세포에 palmitate 로 야기된 지방축적에 대해 아리흑 $70 \%$ 에탄올 추출물은 농 도 의존적으로 세포 내 지방축적을 억제시켰고, 중성지방의 함량 역시, 농도가 높은 $500 \mu \mathrm{g} / \mathrm{mL}$ 처리군에서 낮은 함량을 나타내었다. 본 연구에서는 위의 결과들을 통해 자색밀(아리 흑) 추출물의 plamitate로 인한 세포 보호 효과 및 세포 내 지 방 축적 억제 효과를 확인하였고, 이러한 효능들은 아리흑의
항산화 효과를 통해 기인되었을 것으로 예상된다. 따라서, 우 리는 아리흑의 기능성 소재로의 가능성을 확인하였고, 향후 다양한 연구들을 통해 아리흑이 다양한 분야에서 식품 소재 로의 이용이 가능해지기를 기대해 본다.

\section{요 약}

본 연구에서는 아리흑(자색밀)을 구성하고 있는 유효성분 들을 확인하고, 이들의 생리활성을 확인하고자 하였다. 먼저, 아리흑의 유효성분으로는 gallic acid, protocatechuic acid, caffeic acid, isovanillic acid, p-coumaric 및 ferulic acid로 6 
종을 확인하였다. 총폴리페놀 함량은 아리흑 $70 \%$ 에탄올 추 출물에서 높은 함량을 나타내었고, 총플라보노이드 함량은 물 추출물과 $70 \%$ 에탄올 추출물에서 높은 함량을 나타내었 다. DPPH 자유 라디칼 소거활성은 아리흑 물 추출물 48시간 및 아리흑 $70 \%$ 에탄올 추출물 12 시간에서 유의적으로 높았 던 반면, ABTS 자유 라디칼 소거활성은 추출물간의 유의적 차이는 없었다. MTT assay를 통한 AML-12 세포에서의 세 포 생존율은 아리흑 $70 \%$ 에탄올 추출물에서 높았고, 이는 농 도에 의존적임을 확인하였다. Hoechst staining을 통해 확인 한 apoptosis 보호효과는 아리흑 $70 \%$ 에탄올 추출물을 처리 한 세포에서는 핵의 형태 응축 및 DNA 분절과 같은 형태학 적 특징이 현저히 감소됨을 확인함으로 인해 아리흑 추출물 이 apotosis 억제를 통한 세포생존율을 높임을 확인하였다. Oil-Red-O staining을 통해 확인한 세포 내 지방축적에 대한 아리흑의 효능 평가에서도 $70 \%$ 에탄올 추출물에서 지방축적 억제 효과를 나타냈으며, 이는 농도 의존적으로 감소됨을 확 인할 수 있었다. 이러한 결과들을 통해 아리흑 추출물이 palmitate로 야기된 세포에서 세포생존율, 세포사멸 및 지방 축적에 대해 보호 효과를 확인하였으며, 이는 아리흑의 항산 화 물질들에서 기인한 것으로 아리흑의 항산화 물질들이 항 산화 작용을 통해 위와 같은 결과들을 야기시켰고, 이는 아리 흑이 좋은 항산화 식품으로서 향후 식품에 적용하기 위하여 국내산 아리흑의 생산 및 소비 증진의 방안을 마련하는 데 도움이 될 것으로 기대된다.

\section{Conflict of interests}

The authors declare no potential conflict of interest.

\section{ORCID}

Hee-Yeon Jin https://orcid.org/0000-0002-6258-3219

Young Youn https://orcid.org/0000-0003-4735-1839

\section{References}

Blois MS. Antioxidant determinations by the use of a stable free radical. Nature, 181, 1199-1200 (1958)

Dewanto V, Wu X, Adom KK, Liu RH. Thermal processing enhances the nutritional value of tomatoes by increasing total antioxidant activity. J Agric Food Chem, 50, 30103014 (2002)

Gamel TH, Wright AJ, Tucker AJ, Pickard M, Rabalski I, Podgorski M, Ilio ND, O’Brien C, Abdel-Aal ESM.
Absorption and metabolites of anthocyanins and phenolic acids after consumption of purple wheat crackers and bars by healthy adults. J Cereal Sci, 86, 60-68 (2019) Ham HM, Choi ID, Park HY, Yoon SD, Oh SG, Kim WH, Woo KS. Phenolic compounds and radical scavenging activity of the Korean wheat (Triticum aestivum L.) according to germination times. Korean J Food Nutr, 28, 737-744 (2015)

Hosseinian FS, Li W, Beta T. Measurement of anthocyanins and other phytochemicals in purple wheat. Food Chem, 109, 916-924 (2008)

$\mathrm{Hu}$ C, Cai YZ, Li W, Corke H, Kitts DD. Anthocyanin characterization and bioactivity assessment of a dark blue grained wheat (Triticum aestivum L. cv. Hedong Wumai) extract. Food Chem, 104, 955-961 (2007)

Hyun MR, Lee YS, Park YH. Antioxidative activity and flavonoid content of Chrysanthemum zawadskii flowers. Kor J Hort Sci Technol, 29, 68-73 (2011)

Jo SH, Cho CY, Ha KS, Choi EJ, Kang YR, Kwon YI. The Antioxidant and antimicrobial activities of extracts of selected barley and wheat inhabited in Korean Peninsula. J Korea Soc Food Sci Nutr, 42, 1003-1007 (2013)

Kim HH, Heo MR, Lee SM, Yim SH. Validation of analytical method and antioxidant properties of Eriobotrya japonica Lindl. leaf extract according to extraction solvent. Korean J Food Sci Technol, 51, 301-308 (2019)

Kim IW, Shin DH, Choi U. Isolation of antioxidative components from the bark of Rhus verniciflua STOKES screened from some chinese medical plants. Korean J Food Sci Technol, 31, 885-863 (1999)

Kim KH, Kim KM, Shin DJ, Park HH, Kang CS. A new variety of wheat (KCTC18591P) and food composition for anti-oxidative activity comprising thereof. Korea Patent No. 10-2035666 (2017)

Kim KH, Kim KM, Kim YJ, Shin DJ, Cha JK, Kang CS, Park TI. System development and quality characteristics for diversification of processing and use of colored wheat. Paper Presented Fall Meeting of Korean Society of Crop Scienced, October, 18, Seoul, Korea (2018)

Kim KM, Kim KH, Kim HS, Shin DJ, Kim YJ, Oh MG, Hyun JN. Effect nitrogen fertilize application levels on yield and quality of Korean wheat cultivars. Korean J Agric Sci, 45, 9-18 (2018)

Kim SM, Cho YS, Sung SK. The antioxidant ability and 
nitrite scavenging ability of plant extracts. Korean $\mathrm{J}$ Food Sci Technol, 33, 626-632 (2001)

Kim SS, Chung HY. Comparison of quality analyses of domestic and imported wheat flour products marketed in Korea. Korean J Food Nutr, 27, 287-293 (2014)

Kwak HS, Kim MJ, Kim H, Kim SS. Quality characteristics of domestic and imported commercial plain wheat flour. Korea J Food Sci Technol, 49, 304-310 (2017)

Lee JM, Son ES, OH SS, Han DS. Contents of total flavonoid and biological activities of edible plants. Korean J Dietary Culture, 16, 504-514 (2001)

Lee SJ, Chung HY, Lee IK, Yoo ID. Isolation and identification of flavonoids from ethanol extracts of Artemisia vulgaris and their antioxidant activity. Korean J Food Sci Technol, 31, 815-822 (1999)

Liu Q, Qui Y, Beta T. Comparison of antioxidant activities of different colored wheat grains and analysis of phenolic compounds. J Agric Food Chem, 58, 9235-9241 (2010) Ministry of Agriculture, Food and Rular Affairs (MAFRA).
Agriculture, Food and Rular Affaris Statics. Sejong, Korea, p 312 (2018)

Middleton E, Kandaswami C. Potential health-promoting properties of citrus flavonoids. J Food Technol, 48, 115-119 (1994)

Oh SL, Yang JM, Cha WS, Cho YJ, Kang WW, Kang MJ, Kim KS. Changes in properties of dandelion tea induced by roasting conditions. J East Asian Soc Dietary Life, 10, 129-135 (2000)

Wang MF, Li JG, Rngarajan M, Shao Y, LaVoie EJ, Huang TC, Ho CT. Antioxidative phenolic compounds from sage (Salivia officinalis). J Agric Food Chem, 46, 48694873 (1998)

Yang JW, Son JH, Kang CS, Choi CH, Kim KM, Jung HY, Park JH, Kim YJ, Park TI, Kim KH. Analysis of useful components by extraction solvent of colored wheat and comparison of antioxidant activity. Paper Presented Spring Meeting of Korean Society of Crop Scienced, April, 18, Jinju, Korea (2019) 